\title{
How do Competitive and Regulatory Pressures Interact with Internal Corporate Governance?: Evidence from the Cameroonian Banking Sector
}

\author{
KUATE TALLA Idrice Roméo ${ }^{1}$, KAMDEM David ${ }^{2}$ \\ ${ }^{1}$ Ph.D student in Management, University of Dschang, Cameroon \\ irkuate2000@yahoo.fr \\ ${ }^{2}$ Professor, University of Dschang, Faculty of Economics and Management, Dschang, Cameroon \\ davidkamdem@yahoo.fr
}

\begin{abstract}
The objective of this article is to analyse the impact of both external and internal mechanisms of corporate governance on banks performance in Cameroon. The internal governance mechanisms consist of those linked with the Board of directors (its size and composition) and the ownership structure (ownership concentration, equity capital of each type of shareholder). External mechanisms consist of pressure from competitors, and regulatory pressure from the banking Commission following the adoption of equity principles or rules. Research carried out on a sample of 11 Cameroonian banks showed the effect of complementarity between the control exerted by internal stakeholders (institutional shareholders, insiders' ownership, size of the Board of directors) and competitive pressure. On the contrary, a substitution effect was detected between State administrators and competitive pressure. Results obtained also revealed the substitution effect between control exercised by the Board of directors and regulatory pressure.
\end{abstract}

\section{Indexing terms/Keywords}

Banks, Competition, Regulation, Governance, Performance.

\section{Academic Discipline And Sub-Disciplines}

Finance

\section{Council for Innovative Research}

Peer Review Research Publishing System

\section{Journal: International Journal of Management \& Information Technology}

Vol. 9, No. 2

editor@cirworld.com

www.cirworld.com, member.cirworld.com 


\section{INTRODUCTION}

Due to the banking crisis upsetting the world today, and the numerous shortcomings characterising banks management in recent years, a consensus was reached on the necessity to reinforce bank governance. The Cameroonian economy was not an exception. Cameroon has experienced a banking crisis in the middle of the 1980s until the beginning of the 1990s. To a large extent, this banking crisis was the result of poor corporate governance in the Cameroonian's banking institutions. The symbiotic relationship between the government or political circle and banks contributed to the maintenance of lax prudential regulation and poor corporate governance rules, leading to accumulation of non-performing loans, privileged government financing and breakdown of bank-controlled payment systems. The crisis resulted in a drain of banking bankruptcies. In order to correct these problems, the Cameroonian state and the sub-areas financial institutions restructured the failed banks, adopted new prudential regulation, liberalized the financial sector, and softened monetary policy.

As a result of these reforms, during the decade 2001-2010, the Cameroonian banking sector was marked by the strengthening of prudential supervision after the difficulties faced by banks in the late 1980s. Meanwhile, Capital changes that occurred in Cameroonian banks in favour of financial liberalization had the effect of strengthening the participation of financial holding companies at the expense of the State. Cameroonian banks have undergone a profound change in the shareholding and the board structure. All these changes aim at improving internal corporate governance of Cameroonian banks. At the same time, the restructuring of the banking sector and the entry of new banks in the market have intensified competitive pressure. In this context, the risk of duplication of control is large, which is not without cost to the bank. We therefore examine whether the competitive pressure and regulatory pressure substitute or supplement the various internal controls to mitigate the agency problems and produce a good performance in Cameroonian banks.

Though studies on the interaction between these respective mechanisms have been mentioned by different researchers in different contexts, our work differs with others in many ways. The first contribution of this article is aimed at examining these relationships within the context of Cameroon. In fact, almost all previous researches were carried out based on the American and European contexts. Whereas, Cameroon banking context has some specificities. Firstly, bank ownership is concentrated, contrary to the case of the United States and Europe where ownership is dispersed. More so, several modification of banking regulation in the CEMAC ${ }^{1}$ since 2001 renders the context exceptional. Even if these modifications take its root from the Cooke's Regulation with an almost universal application, it however differs with regard to the original character of risk weighting. Another particularity of the context is that the Cameroon banking sector is dominated by foreign banks affiliates ${ }^{2}$. Lastly, the financial market is underdeveloped. These specificities of the context can give rise to governance mechanisms with different characteristics, thereby permitting an ideal framework to enrich the theory on banking governance.

Another contribution offered by this work entails verifying whether the combination of both the internal and external governance mechanisms, has a direct impact on the performance of Cameroonian banks. In this regard, the study on the connection or link (complementarity/substitution) which could exist between the various governance mechanisms, could enable banks to avoid double control and instead increase the wealth of shareholders.

The remainder of the paper is structured as follows. First, we propose a review of the existent literature on the interaction between the internal and external governance mechanisms (section 2), which forms a basis for our proposed models of the issues (section 3), before reporting the results of our study on a Cameroonian sample (section 4). Finally, Section 5 concludes this study.

\section{LITERATURE REVIEW}

The agency theory is based on the assumption that separation between ownership and decision leads to conflict between managers and shareholders because they have opposing objectives. In order to reduce these conflicts, this theory offers control mechanisms on how to discipline managers and oblige them to work in the interest of owners. These mechanisms could either be internal or external. Ownership structure and the Board of directors are often considered primary mechanisms for internal control (Shleifer and Vishny, 1997), meanwhile external mechanisms regroup the major markets (labour market, markets for goods and services, and the capital market), and the legal framework of each country. In the following, we present a summary of recent studies that have been conducted regarding the relationship between external and internal corporate governance.

\subsection{Interactions Between the Internal Corporate Governance and Competitive Pressure}

Alchian (1950) demonstrates that high product market competition induces firms to lower their production costs, to finance capital at lower cost, and to increase internal corporate governance. Only a relatively few papers have documented the interaction between product market competition and internal corporate governance. One line of inquiry examines the effects of product market competition on internal corporate governance.

\footnotetext{
${ }^{1}$ The Central Africa Economic and Monetary Community (CEMAC) groups six countries including Cameroon, Central African Republic, Congo, Gabon, Equatorial Guinea and Chad.

${ }^{2}$ Ten banks over the twelve operating in 2010 in Cameroon are affiliates of foreign banks.
} 
Karuna (2010), find that firms operating in highly competitive industrial sector have smaller boards, more outsider directors on the board, a higher likelihood of the CEO and chairman-of-the-board roles being separate. More so, shareholder rights are much stronger. This result suggests a positive relationship between competition and the intensity of internal governance mechanisms. Meanwhile, the author shows that the Board size and the proportion of independent administrators increase with competition at a decreasing rate, proving therefore that competition has a non monotonous relationship with these internal governance mechanisms. This non-monotonic positive relation between competition and governance strength documented by Karuna sheds light on the theoretical debate as to whether competition (commonly regarded as external governance) acts as a complement or substitute to monitoring (internal governance) in firms. In particular, the finding shows that while competition generally complements internal governance mechanisms, it acts as a disciplinary mechanism and becomes more of a substitute to such mechanisms at higher levels of competition. In this regard, it also contributes to the literature on delegation and monitoring. Prior studies show that when firms delegate authority to their managers, they need to have additional monitoring mechanisms in place to curb potential harmful actions by these managers using their discretion (e.g., Prendergast, 2002). Karuna (2010) suggest that competition plays an important moderating role in the relation between delegation and monitoring by showing that when competition becomes intense, delegation and monitoring may act more like substitutes to each other.

Another line of studies investigates the roles of external and internal corporate governance on the performance or value of firms. Grosfeld and Tressel (2001) determine that high product market competition has a significant and positive effect on firm productivity only when ownership structure is concentrated. Li and Niu (2006), prove the contrary of this result in that firms with moderated shareholding concentration are more productive in a competitive environment, whereas firms with concentrated shareholding have low productivity in a competitive environment. Nickell et al. (1997) considers the joined effect of competition in the product market, shareholders control, and the level of indebtedness on the productivity of British firms. Their results reveal the positive influence of competition, major shareholders control and financial pressure on the growth of productivity. Furthermore, they illustrate that financial pressure and major shareholders control substitute competition. To that end, the impact of competition on productivity being lesser when firms are more indebted or when they have a strong shareholder. Januszewski et al. (1999) on their part, portrays that competition has a positive impact on the growth of firms productivity with concentrated shareholding; this confirms then the complementarity between competition and concentrated shareholding. In the same light, Koke (2001) also proves complementarity between competition and concentrated shareholding amongst German firms. He demonstrates that when shareholders control is strong, competitive pressure spurs firms productivity. In India, Manoranjan and Pant (2010), underlines the complementarity link between insiders' ownership and competition. The authors show that firms in which managers own greater capital share are only performant when competition is high in the product market.

Randøy and Jenssen (2004), on their part suggest that firms in highly competitive industries should have few external administrators meanwhile firms operating in lowly competitive industries should have a greater number of external administrators. The authors show that the Board's independence is less appropriate or even unnecessary in highly competitive environments, where the firm is «already disciplined " by a competitive market. Based on a sample of Swedish firms their study revealed that the independence of the Board diminishes the performance of firms operating in a competitive market, whereas it increases the performance of firms when the market is less competitive.

Collectively, evidence from these studies consistently demonstrates that product market competition induces firms to secure better internal corporate governance, and that the positive influence of internal corporate governance on firm value is diminished when the product market is more competitive. Firms tend to improve their internal corporate governance given a more competitive product market environment, thus increasing the probability of their survival, but the marginal impact of internal corporate governance on firm value would be lower if product market competition works to discipline managers.

However, some firms that are less subject to product market threat may not necessarily improve their internal corporate governance under product market competition conditions. Park et al (2011) claim that firms belonging to a business group, firms with larger asset size, and firms occupying a dominant position in an industry may not be sufficiently threatened to improve their internal corporate governance under conditions of increasing product market competition. On the other hand, these are firms with a greater incentive to establish good internal corporate governance under non-competitive product market conditions, since they have more to lose as larger and dominant players in the market if neither internal nor external corporate governances are successful. They also have the internal resources to set up good internal corporate governance in cases in which external corporate governance does not work, which might prove costly for smaller, standalone firms. Accordingly, larger firms or firms belonging to a large business group will tend to have better internal corporate governance and commit to disciplined behavior to outside investors when external corporate governance does not work (La Porta et al., 2000).

Park et al (2011) empirically confirm that firms that are less subject to product market competition would have more incentive to strengthen their internal corporate governance when they lack product market competition in their industries, while they have less incentive to improve their internal corporate governance when external corporate governance does work successfully. They also find that other firms that are more likely to be exposed to the threat of product market competition tend to strengthen their internal corporate governance when product market competition intensifies. Thus, depending on the extent to which firms are subject to product market competition, their decisions regarding internal corporate governance vary given product market conditions. 


\subsection{Combination of Internal and Regulatory Mechanisms}

Corporate governance of banks is characterized by internal mechanisms designed to influence and monitor the manager's behavior, but also by external mechanisms such as regulation, which are extremely important in this sector.

Booth et al. (2002) studied the possibility of substituting internal and external mechanisms at the level of banks governance. They look at four mechanisms for managerial discipline: one external mechanism, regulation, and three internal mechanisms: board member independence, share ownership by the manager and separation of the functions of manager and chairman of the board. Booth et al. explain that one of these four mechanisms may be more important in managing divergent interests in a shareholder approach. In highly regulated sectors like the banking sector, the discipline exercised by regulation is replacing banks' internal governance mechanisms and therefore limiting his latitude for action. This ties with other studies carried out by Maroto-Acin and Hernandez (2000) and Prowse (1997). To them, banks bear moral risks from their debtors, who profit from the asymmetric information in the framework of the traditional bank borrower relationship. The intervention of regulatory authorities enable the influencing of banks internal activities (management of risk positions, provision policy, capital requirement...). Regulatory authorities play the role of efficient parapet to safeguard the interest of shareholders and depositors (Maroto-Acin and Hernandez, 2000) and oblige banks as if they received mandate from shareholders and depositors to implement this control (Prowse, 1997). According to these authors, regulatory authorities are active participants towards banks and a delegation of control of the manager is indirectly assigned them by shareholders and depositors. However, there is no convergence in the interest of regulatory authorities and shareholders with regard to risk bearing. In effect, shareholders by reason of diversification of their portfolio will accept to bear a greater part of bank risk in return for high profitability, meanwhile regulatory organs would oblige the manager to limit such excessive risks through a number of regulatory instruments.

However, faced with these double inversely related constraints, Booth et al. (2002) concluded on the substitution of these discipline mechanisms of the manager. This study based on a large sample of firms from varying regulatory sectors proves that regulation as an external discipline mechanism is used as a way of checking the decision taken by the manager. Regulation reduces the impact of managerial decisions on the wealth of shareholders, leading virtually to the substitution between regulation and internal governance mechanisms which become less effective in curbing principalagent conflict. In essence, the presence of a regulatory authority intervening in the discipline of the manager greatly limits the discretionary power of the latter. Thus, control by regulatory organ constitutes an alternative to the control carried out by independent administrators within the board, share ownership by the manager and separation of the functions of manager and chairman of the board.

According to Bouaiss and Marsal (2009), this « effect of substitution » however has to be relative for the authors seek to test further the intensity of internal mechanism (percentage of independent administrators, percentage of shares owned by management team) instead of the replacement of one mechanism by another. The presence of a "devoted" regulator within the banking sector diminishes the intensity of internal governance mechanism.

In their studies on French banks, Alexandre and Bouaiss (2008) show that the regulatory discipline is exercised effectively on French banks: improvement of capitalization and a decline in risk-taking help to improve the performance of these banks. Similarly, a reciprocal increase in performance and risk-taking explains the rise in capitalization, and the increase in performance and decline in capitalization explain the decline in risk-taking by these banks. These results indicate that the regulatory discipline imposed by the Basel Committee has an effective influence on French banks. Alexandre and Bouaiss (2008) also show that the regulatory discipline acts in complement to the discipline exercised by shareholders. Supervision by the board of directors through the presence of independent directors and director-managers who are also managers of other firms disciplines the manager, resulting in an improvement of performance by effective management of the riskreturn tradeoff. Also, experience and the number of CEO positions held by the manager, which reflect his managerial latitude, show that the manager manages his bank in the interests of shareholders, investing in risky activities while respecting the external governance constraints imposed by the Basel Committee. Concerning this study carried on French banks, it stands out that managers can satisfy the profit exigencies of shareholders with a certain degree of risk taking which visibly is sufficiently covered by the dispositions put in place by the Basel committee. In this wise, the complementarity of the internal and external discipline mechanisms enable the manager to satisfy the need of shareholders within the framework of risk outline by regulatory instrument.

\section{METHODOLOGY}

\subsection{Sample and Variables}

Our samples constitute of individual data obtained from 11 banks operating in Cameroon. The temporary data cover a period of 10 years, from 2001 to 2010. Thus, we shall use panel data with a cross-sectional and a time series dimension.

Data on the composition of banks Board were extracted from several bank directories and financial established as published by the Bank of Central African States (BEAC) and supplemented or validated by resource persons of the banks in question. Data related to banks ownership structure were gotten from annual reports produced by the Banking Commission of Central Africa (COBAC), meanwhile the rest of the data was obtained using the balance sheet and the income statement published by these banks in their annual activity reports. Table 1 defines the variables used and their respective measures. 
Table 1: Definitions and variable measures

Variables Measure retained with reference to previous studies

Ownership structure

CKTAL : Shareholding concentration. Cumulative percentage from three major shareholders arranged in decreasing order of importance.

CAPIN : Insider ownership: part of capital in the holding of $\mathrm{CEO}^{3}$, executives and administrators.

CAPINST : Percentage of capital held by institutions

CAPETAT : Percentage of capital held by the State

\section{Board structure}

TCA

: Total number of administrators within the bank

ADEXT : Board independence measured by the percentage of external administrators present in the Board.

ADINST : Percentage of administrators representing financial institutions in the Board

ADETAT : Percentage of administrators representing the state in the Board

\section{Regulatory pressure}

REG1 : This is the difference between bank solvency ratio and the minimum required by the regulation. This variable enable us to measure the degree of surplus or insufficiency in the bank's equity capital. Bouaiss (2008)

REG2 : It is the product between the distance to the statutory level, (REG1), and the bank's solvency ratio at the begining of the period $\left(\mathrm{CAP}_{\mathrm{t}-1}\right)$. This variable measures speed at which the bank adjusts its capital adequacy ratio to regulatory requirements, Bouaiss (2008).

\section{Competitive pressure}

MKTSH $_{\mathbf{c}}$ : Bank's share in the market (in terms of loans).

CR4c : Concentration ratio. Ratio indicating the share requested by the first four banks (in terms of credit).

Factors of production

$\mathbf{L}$

: Labour : Total staff employed

K : Physical capital $=$ net Fixed Assets + capital stock depreciated + Leasing .

F : Financial resources of the bank $=$ respective creditors' accounts + Cash certificate + securities + participative loans

\section{Dependent variables (performance)}

ROA : Return on assets, that is, profit divided by total assets.

Y : Productivity : Ratio of total credits to the number of workers

\section{Other endogenous variables}

CAP : Banks capitalisation level, measured by equity capital ratio on total assets

RISK : Doubtful debt ratio to total credit. This ratio is a measure of the loan portfolio quality. An increase in this ratio indicates a decrease in loan portfolio quality, and implies a high default banking risks

\subsection{Empirical Models}

To give an answer to our research objective, we use two models. The first model is based on the functional Cobb-Douglas form. We relate the productivity of banks, measured by the ratio of total credits to the number of workers, to three factors of production: labor, physical capital and financial resources of banks. This model is augmented with a set of variables that capture the influence of product market competition and corporate governance on bank's productivity. We take logs and include lagged output as an explanatory variable to allow for endogenous persistence. We also allow for unobserved firm heterogeneity and include an error term, $\varepsilon_{i t}$, which is assumed to be serially uncorrelated over time. Finally, we

\footnotetext{
${ }^{3}$ CEO or Chief Executive Officer
} 
parameterize productivity as a linear function of the firm-specific measure of competition, and a set of corporate governance variables (ownership, board structure). We also include interaction terms between competition and internal governance mechanisms; which eventually help us to discuss probable complementarity or substitution between these disciplinary mechanisms. Finally, our first model is written thus:

$y_{i t}=\beta_{0}+\beta_{1} y_{i t-1}+\beta_{2} I_{i t}+\beta_{3} k_{i t}+\beta_{4} f_{i t}+\beta_{5} C O N_{i t}+\beta_{6} C G_{i t}+\alpha_{j} C O N_{i t} C G_{i t}+\varepsilon_{i t}$

In this equation, $y_{i t}, l_{i t}, k_{i t}$ and $f_{i t}$ respectively represent the logarithm of productivity, labour, physical capital and bank's financial resources.

Subscripts i denotes individual banks, t time period

$\mathrm{CON}_{\mathrm{it}}$ stands for competitive pressure weighing on the bank

$\mathrm{CG}_{\mathrm{it}}$ is an internal governance variable

$\mathrm{CON}_{\mathrm{it}} \mathrm{CG}_{\mathrm{it}}$ stands for the interaction term

$\varepsilon_{\text {it }}$ is the error term

The second model is derived from theoretical and empirical works that analysed the impact of capital regulation on the behaviour of risk taking in banks and the firms governance theory (Alexandre and Bouaiss, 2008 ; Shrieves and Dahl, 1992). The modelling suggested enables us to understand how the pressure exerted by regulation and that exerted by shareholders through the Board both react on the behaviour of bank managers with regard to risk bearing, the search for performance and the respect for adequate capitalisation.

Below are equations for regressions.

The first equation concerns capital level variation $(\triangle \mathrm{CAP})$

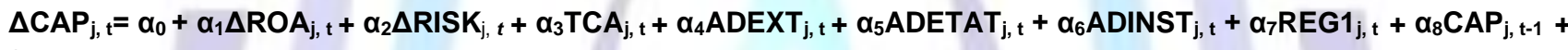
$\varepsilon_{\mathrm{j}, \mathrm{t}}$.

The second equation concerns risk level variation.

$\Delta$ RISK $_{\mathrm{j}, \mathrm{t}}=\beta_{0}+\beta_{1} \Delta \mathrm{ROA}_{\mathrm{j}, \mathrm{t}}+\beta_{2} \Delta \mathrm{CAP}_{\mathrm{j}, \mathrm{t}}+\beta_{3}$ TCA $_{\mathrm{j}, \mathrm{t}}+\beta_{4} \mathrm{ADEXT}_{\mathrm{j}, \mathrm{t}}+\beta_{5} \mathrm{ADETAT}_{\mathrm{j}, \mathrm{t}}+\beta_{6}$ ADINST $_{\mathrm{j}, \mathrm{t}}+\beta_{7} \mathrm{REG1}_{\mathrm{j}, \mathrm{t}}+\beta_{8} \mathrm{RISK}_{\mathrm{j}, \mathrm{t}-1}$ $+\mu_{\mathrm{j}, \mathrm{t}}$.

The third equation indicates performance evolution

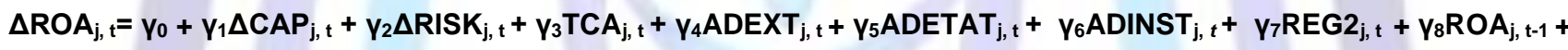
$\mathbf{V}_{\mathrm{j}, \mathrm{t}}$

The three endogenous variables of the model are interdependent. In fact, an increase in equity capital could equally raise increase the capital cost of banking establishment which consequently would seek for high profitability. In addition, an increase in equity capital would increase induced risk through the extension of portfolio to more risky and productive assets earnings. Besides, banks with less profits are tempted to grant uncertain loans and to plunge themselves into uncertain activities to secure their profitability and respect capital norms dictated by monetary authorities.

The first model enables the testing of the effect of interaction between competitive pressure and the various internal governance mechanisms on performance. The second model enables us to capture the effect of interaction between regulatory pressure and the internal governance mechanisms on banks performance.

\section{EMPIRICAL RESULTS}

After presenting the different models, we are going to proceed to their empirical validation while using data from Cameroon banking sector. A descriptive study of our sample is suggested first, followed by models estimation.

\subsection{Descriptive Study of the Cameroon Banking Sector from 2001 to 2010}

The choice of our explicit variables was guided essentially by recent empirical studies which show clearly the interaction between internal and external governance mechanisms. Descriptive statistics of the variables used as well as their evolution during the period of study are hereby presented below.

\subsubsection{Evolution of Banks Solvency Ratio}

Descriptive analysis of our sample of 11 Cameroonian banks is first based on regulatory ratios (solvency ratio) as presented in the below table.

Table 2: Average solvency ratio of banks operating in Cameroon from 2001 to 2008

\begin{tabular}{|l|l|l|l|l|l|l|l|l|}
\hline & 2001 & 2002 & 2003 & 2004 & 2005 & 2006 & 2007 & 2008 \\
\hline overall sample (\%) & 9 & 8.75 & 9.63 & 11 & 13.7 & 13.91 & 18.8 & 18.7 \\
\hline Subsidiaries of foreign banks (\%) & 8.17 & 8.5 & 9.5 & 10.33 & 16.5 & 23.83 & 26.3 & 21.8 \\
\hline
\end{tabular}




\begin{tabular}{|l|l|l|l|l|l|l|l|l|}
\hline Local banks (\%) & 10.67 & 9.5 & 10 & 12 & 9.5 & 2 & 7.5 & 14 \\
\hline
\end{tabular}

Source : our calculations

In view of the evolution since 2001 to 2008 , in Table 2, we see that overall solvency ratios are well above the regulatory requirement of $8 \%$. Indeed, we find a continuous upsurge beyond the average of $8.75 \%$ over the period. This finding may be related to the fact that banks maintain a high level of capital for reasons such as reputation and the rating value assigned by the Banking Commission ${ }^{4}$... These descriptive data are indicative of the safety measures that Cameroonian banks acquired during the year 2000s and confirms the contention that banks wanted a capital cushion to protect against possible financial difficulties.

\subsubsection{Evolution of Competitive Pressure}

Over the 2001-2010 decade, the Cameroonian banking sector was dominated by four banks which occupied about 68 $75 \%$ of the market for loans and deposits. Other banks remained at a marginal level. The table below allows you to appreciate the evolution of the market shares of the four largest banks in Cameroon during the period from 2001 to 2010.

Table 3: Evolution of market share of the four strongest banks in Cameroon (index of concentration of the banking market, CR4)

\begin{tabular}{|l|l|l|l|l|l|l|l|l|l|l|}
\hline & 2001 & 2002 & 2003 & 2004 & 2005 & 2006 & 2007 & 2008 & 2009 & 2010 \\
\hline In terms of deposits (\%) & 78.4 & 74.8 & 72.2 & 71.8 & 68.4 & 69.1 & 69.9 & 67.8 & 66.5 & 65.2 \\
\hline In terms of credits (\%) & 75.3 & 71.9 & 69.5 & 66.4 & 69.5 & 70.1 & 71 & 67.9 & 68.4 & 69.3 \\
\hline In terms of total balance sheet (\%) & 77.5 & 73.7 & 70.1 & 69.6 & 67.1 & 68.6 & 68.3 & 66.6 & 66.8 & 67.6 \\
\hline
\end{tabular}

Source: Authors' calculations from COBAC data

Table 3 shows a gradual downward trend in concentration ratios of the Cameroonian banking market, both for credits and for deposits. This reflects the intensifying competition in the Cameroonian banking market from 2001 to 2010.

\subsubsection{Evolution of internal governance variables}

The ownership of banks operating in Cameroon is dominated by financial holding companies and credit institutions. The State's participation in the capital of banks has declined by more than half over the past decade, showing the withdrawal of government from the banking business. The ownership of banks in Cameroon is highly concentrated. The first three shareholders hold on average between 74.4 and $85.7 \%$ of the capital over the period of the study as shown in Table 4 below.

Table 4: Changes in the ownership structure of banks in Cameroon (\%)

\begin{tabular}{|c|c|c|c|c|c|c|c|c|c|c|}
\hline & 2001 & 2002 & 2003 & 2004 & 2005 & 2006 & 2007 & 2008 & 2009 & 2010 \\
\hline Share of capital held by institutions & 65.2 & 64.5 & 62.7 & 63.4 & 63.4 & 64.2 & 64.2 & 63.2 & 81.9 & 80.7 \\
\hline $\begin{array}{l}\text { Including financial holding } \\
\text { companies and local banks }\end{array}$ & 53.8 & 51.8 & 51.4 & 51.2 & 52.9 & 55.4 & 51.4 & 57.2 & 61.9 & 67.4 \\
\hline $\begin{array}{l}\text { Including companies other than } \\
\text { banks }{ }^{5}\end{array}$ & 11.4 & 12.7 & 11.3 & 12.2 & 10.5 & 8.8 & 12.8 & 6 & 20 & 13.3 \\
\hline $\begin{array}{l}\text { Percentage of capital held by } \\
\text { individuals }\end{array}$ & 23.8 & 27 & 26.8 & 26.7 & 28.4 & 29.1 & 29.3 & 31.4 & 12.6 & 13.4 \\
\hline Including employees & 0.41 & 0.32 & 0.31 & 0.31 & 0.28 & 0.24 & 0.24 & 0.34 & 0.34 & 0.34 \\
\hline $\begin{array}{c}\text { Including executives and } \\
\text { administrators }\end{array}$ & 12.9 & 12.7 & 17.2 & 15.5 & 10.6 & 10.3 & 11.2 & 11.4 & 6.6 & 5.0 \\
\hline $\begin{array}{l}\text { Percentage of capital held by the } \\
\text { State }\end{array}$ & 11.04 & 8.52 & 10.51 & 9.95 & 8.19 & 6.78 & 6.49 & 5.42 & 5.42 & 5.33 \\
\hline $\begin{array}{l}\text { Share capital of the top } 3 \\
\text { shareholders }(\%)\end{array}$ & 74.44 & 76.78 & 79.54 & 77.34 & 77.53 & 76.86 & 76.80 & 79.47 & 84.90 & 85.70 \\
\hline
\end{tabular}

Source : authors' calculations

\footnotetext{
${ }^{4}$ In June 2000, the Banking Commission adopted a rating system known as "SYSCO" and based on five pillars (capital adequacy, asset quality, management and internal control, liquidity and profitability)
}

${ }^{5}$ These are especially insurance companies. 
Table 5 below shows the evolution of the structure of the board of directors of banks in Cameroon from 2001 to 2010 . Reading through this table, we see that the average number of directors is 7 to 8 in Cameroonian banks throughout the study period. This average is similar to that reported by Dannon (2010) for the size of the board of directors of banks in the WAEMU zone (7.38 over the period 1996-2007). Also, this table shows that in the Cameroonian banking sector, the use of independent directors is far from common in business practice. Although the Cameroonian banks are majority-owned by institutions, these have less weight in the board. Finally, we note that even if the State has gradually withdrawn from the banking business over the past decade, its presence on the board of directors of the banks was rather enhanced.

Table 5: Evolution of the structure of the board of directors in Cameroonian banks

\begin{tabular}{|l|l|l|l|l|l|l|l|l|l|l|}
\hline & 2001 & 2002 & 2003 & 2004 & 2005 & 2006 & 2007 & 2008 & 2009 & 2010 \\
\hline Average size of the Board of Directors & 8 & 8 & 7.9 & 7.9 & 8 & 8.1 & 7.6 & 7.7 & 8 & 8 \\
\hline \% of external directors & 4.9 & 4.9 & 5 & 4.9 & 4.9 & 6.6 & 5.2 & 5.8 & 7.4 & 7.4 \\
\hline \% of institutional directors & 32.3 & 32.3 & 29 & 29.3 & 30.2 & 29.9 & 31.5 & 33.5 & 42.9 & 40.9 \\
\hline \% of directors representing the State & 7.1 & 7.1 & 6.9 & 7.2 & 7.2 & 7.2 & 6.4 & 7.4 & 8.2 & 9.8 \\
\hline
\end{tabular}

Source : authors' calculations

In brief, the changes described above enables us to notice that during the decade 2001-2010, Cameroonian banks had a capital cushion. Capital changes that occurred in Cameroon banks in favour of financial liberalization had the effect of strengthening the participation of financial holding companies at the expense of the State. Cameroonian banks have undergone a profound change in the shareholding structure. At the same time, competition has intensified in the Cameroonian banking market. It remains to be seen how this evolution of internal governance structures is combined with competitive pressure and regulatory pressure to discipline bank managers and what was the impact of these interactions on the performance of banks in Cameroon.

\subsection{Internal Governance Mechanisms, Competitive Pressure and Performance of Banks in Cameroon.}

The first model allows us to test the effect of the interaction between competitive pressure and various internal governance mechanisms on performance. It is a dynamic panel model because it incorporates a lag of the dependent variable as an explanatory variable. For such a model, standard econometric techniques like the Ordinary Least Squares (OLS), does not provide efficient estimates, due to the presence of the lagged dependent variable on the right-hand side of the equation. On the contrary, the Generalized Method of Moments (GMM) provides an efficient estimation of such a model by enabling the control of individual and time specific effects and mitigates the endogeneity of explanatory variables.

There are two types of GMM estimators in dynamic panel: the GMM estimator in first difference and the GMM estimator in system. The GMM estimator in first difference developed by Arellano and Bond (1991) consists of taking for each period the first difference of the equation to estimate in order to eliminate the individual specific effects, and then instrument the explanatory variables in the equation in the first difference by their values in lagged level of a period or more. This method has the advantage of taking into account the errors autocorrelation generated by the first differentiation.

As for the Blundell and Bond system estimator (1998), it combines the equations in first difference with the level equations in which the variables are instrumented by their first differences. Blundell and Bond (1998) showed that the GMM system estimation is more efficient in finite samples when the instruments are "weak."

To choose between the two estimators, Bond (2002) proposed to estimate an autoregressive model of order 1 for each explanatory variable to assess its "persistence". If for some variables, the autoregressive coefficient is close to 1 , the Blundell and Bond "GMM System " estimator is preferred. If not we keep the "GMM difference " estimator (Arellano and Bond, 1991).

Three variables are characterized by an autoregressive coefficient between 0.9 and 1 . If you want to keep them in the specifications, the estimate of the "system GMM" method should be preferred. Our sample of 11 banks observed between 2001 and 2010 has an appropriate time dimension. However, the individual dimension is itself relatively small. This is why we limit the number of potential instruments to two (t-2 and t-3). Following the recommendations of Bond (2002), only onestep procedure with standard error correction is used. The estimation results of specifications for "system GMM" are presented in the tables below.

Table 6: Impact of the combination of competition and ownership structure on the performance of banks.

\begin{tabular}{|c|c|c|c|c|c|c|}
\hline \multicolumn{2}{|c|}{ Explanatory variables $\downarrow$} & \multicolumn{5}{|c|}{ Model Specifications } \\
\hline $\begin{array}{l}\text { Autoregressive term } \\
\Delta \mathrm{Y}(-1)\end{array}$ & L.logprodu y & $\begin{array}{l}0.321^{\star \star \star} \\
(2.736)\end{array}$ & $\begin{array}{l}0.230^{\star \star \star} \\
(2.742)\end{array}$ & $\begin{array}{l}0.165^{\star \star \star} \\
(3.496)\end{array}$ & $\begin{array}{l}0.426^{\star \star \star} \\
(2.898)\end{array}$ & $\begin{array}{l}0.374^{\star \star \star} \\
(3.327)\end{array}$ \\
\hline & loglabor & $-0.584^{* * *}$ & $-0.892^{\star \star *}$ & $-1.099^{\star \star \star}$ & -0.319 & $-0.550^{\star *}$ \\
\hline
\end{tabular}




\begin{tabular}{|c|c|c|c|c|c|c|}
\hline \multirow{5}{*}{$\begin{array}{l}\text { Factors of } \\
\text { production }\end{array}$} & & $(-4.815)$ & $(-5.108)$ & $(-10.639)$ & $(-0.811)$ & $(-2.054$ \\
\hline & $\log K$ & -0.020 & 0.012 & 0.005 & -0.030 & -0.021 \\
\hline & & $(-1.403)$ & $(0.621)$ & $(0.494)$ & $(-1.028)$ & $(-0.920)$ \\
\hline & $\log \mathrm{F}$ & $0.547^{* * *}$ & $0.427^{* \star \star}$ & $0.474^{\star * *}$ & $0.451^{\star * *}$ & $0.534^{\star * *}$ \\
\hline & & $(5.844)$ & $(4.091)$ & (6.919) & $(2.872)$ & $(3.814)$ \\
\hline \multirow{8}{*}{ Ownership structure } & cktal & & 0.002 & & & \\
\hline & & & $(0.677)$ & & & \\
\hline & capin & & & $-0.003^{\star \star}$ & & \\
\hline & & & & $(-2.266)$ & & \\
\hline & capinst & & & & -0.002 & \\
\hline & & & & & $(-1.055)$ & \\
\hline & capetat & & & & & 0.003 \\
\hline & & & & & & $(0.212)$ \\
\hline Competition & $\mathrm{mktsh}_{\mathrm{c}}$ & & $-0.064^{*}$ & $-0.027^{* \star \star}$ & -0.064 & 0.007 \\
\hline & & & $(-1.75$ & $(-8.337)$ & $(-1.352)$ & $(0.483)$ \\
\hline \multirow{8}{*}{ Interaction terms } & $\mathrm{mktsh}_{\mathrm{c}}{ }^{*} \mathrm{cktal}$ & & -0.000 & & & \\
\hline & & & $(-1.391)$ & & & \\
\hline & mktsh $_{\mathrm{c}}{ }^{*}$ capin & & & $-0.001^{\star \star \star}$ & & \\
\hline & & & & $(-4.254)$ & & \\
\hline & mktsh $_{c}{ }^{*}$ capinst & & & & $-0.001^{*}$ & \\
\hline & & & & & $(-1.661)$ & \\
\hline & $\mathrm{mktsh}_{\mathrm{c}}{ }^{*}$ capetat & & & & & -0.000 \\
\hline & & & & & & $(-0.431)$ \\
\hline & _cons & $4.445^{\star \star \star}$ & $6.059^{\star \star \star}$ & $6.982^{\star \star \star}$ & $3.642^{* *}$ & $3.952^{\star * \star}$ \\
\hline & & $(4.073)$ & $(7.351)$ & $(16.041)$ & $(2.503)$ & $(3.641)$ \\
\hline \multicolumn{2}{|l|}{$p$-value Wald test } & 0.000 & 0.000 & 0.000 & 0.000 & 0.000 \\
\hline \multicolumn{2}{|c|}{ p-value Sargen/ Hensen test } & 0.104 & 0.062 & 0.105 & 0.412 & 0.126 \\
\hline \multicolumn{2}{|c|}{$p$-value $A R(1)$ test statistics } & 0.003 & 0.031 & 0.002 & 0.024 & 0.007 \\
\hline \multicolumn{2}{|c|}{$p$-value $A R(2)$ test statistics } & 0.101 & 0.802 & 0.258 & 0.133 & 0.208 \\
\hline
\end{tabular}

Superscripts ${ }^{*},{ }^{* *},{ }^{* *}$ indicate statistical significance at $10 \%, 5 \%$, and $1 \%$ levels, respectively; t statistics in parentheses.

Two tests are associated with the GMM dynamic panel: the over-identification test of Sargan / Hansen tests the validity of the lagged variables as instruments, and the Arellano and Bond autocorrelation test where the null hypothesis is the absence of serial correlation of second-order in the first differenced standard errors. The P-value of the Sargan -Hensen test being greater than 0.05 , the instruments are valid. The autocorrelation tests errors presented in the last two rows of the table (no autocorrelation of order 2) validate the choice of lags of two periods of the endogenous variables as instruments (Bond, 2002). The Wald test gives the significance level required to reject the null hypothesis that the explanatory variables are jointly equal to zero.

After reading the table, a number of significant results come out clearly.

An examination of the columns in this table indicates the importance of financial capital in the explanation of the level of labour productivity in Cameroonian banks. We also note that the level and the significance of the coefficient of lagged productivity confirm the need to include this effect in our model. The fact that productivity is correlated with its lagged value means that performance creates performance. Banks with high productivity are more likely to see this continue and extend productivity over time.

Columns (4) and (5) show that the loan market shares (mktshc) have a significant impact on productivity. Therefore, banks facing intense competition in the loan market seem to be more productive. This result suggests that competition generates a strong incentive for managers to work diligently. On the contrary, none of the variables related to the ownership structure improves the productivity of Cameroonian banks. In addition, two complementary relationships appear. The first is the 
complementary relationship between competition and ownership of institutions (statistically significant at $10 \%$ ). The second is the complementary relationship between competition and insiders' ownership (fraction of capital held by the managers, and directors). These complementary relationships show that these types of shareholder exercise more effective control when competition increases in the loan market and help make the bank most productive.

Our results confirm those of Karuna (2010), Ammann et al (2010) and Giroud and Mueller (2011), which found that competition in the product market leads to a strengthening of internal governance mechanisms. However, for these authors, the positive influence of internal governance mechanisms on performance decreases when the competition got tougher on the product market. In other words, firms tend to improve their internal governance in a highly competitive environment, thus increasing the likelihood of their survival. But the marginal effect of internal governance mechanisms on performance is lower if the discipline imposed on the managers by the product market is strong.

Table 7: Impact of the combination of competition and the Board of directors on the performance of banks

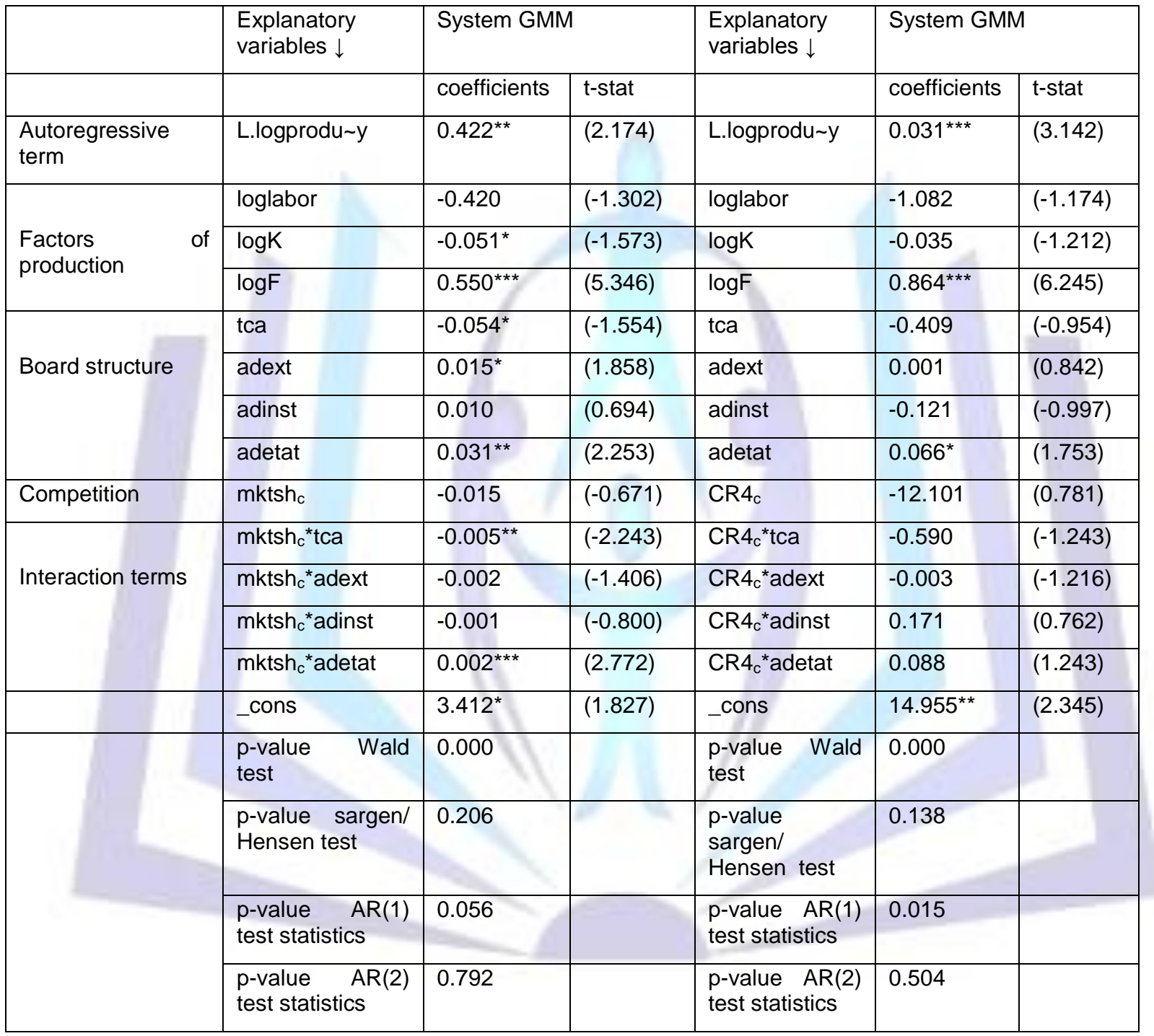

Superscripts ${ }^{*},{ }^{\star \star},{ }^{\star \star *}$ indicate statistical significance at 10\%,5\%, and $1 \%$ levels, respectively; t statistics in parentheses.

We first note that the over-identification test of Sargen-Hensen and the second order autocorrelation test do not reject the hypothesis of validity of lagged variables in level and in difference as instruments and the assumption of absence of a second order autocorrelation of errors. We also note a negative and significant relationship between physical capital and productivity. This can be explained by the fact that Cameroonian banks are in the expansion phase and have high amounts of used fixed assets which have not yet started to boost productivity.

In addition, the combination of competition and the Board of directors as an internal governance mechanism shows the existence of two significant relationships (one negative and one positive). The positive association between internal governance mechanisms and market share (an inverse measure of competition) reinforces the substitution hypothesis proposed by Nickell et al (1997). Our results support the existence of substitutability between competition and the percentage of directors representing the State in the board. In other words, the directors representing the State are not considered good controllers, acting in the best interest of the bank when competition intensifies. 
In addition, there is a complementary relationship between the size of the board of directors and competition. This indicates that as far as competition intensifies and the environment becomes more complex, Cameroonian banks expand the size of the board, to benefit from the diverse skills of the directors, their expertise and their advice on new methods and new strategies. Thus, a large board is combined with a strong competitive pressure to improve the performance of banks in Cameroon.

The following paragraph shows the relative influences of board discipline and regulatory demands in respect of the manager's triple objective of maintaining a required capitalization level, taking risks and achieving good performances.

\subsection{Internal Governance Mechanisms, Regulatory Pressure and Performance of Banks in Cameroon}

The second model developed enables us to capture the effect of the interaction between regulatory pressure and internal governance mechanisms on the performance of banks. The estimation results of our system of equations are given in the table below. We use the Two-stage least-squares method and the Three-stage least-squares method, the Hausman test allows us later to discriminate between the two methods.

Table 8: Interactions between internal governance mechanisms and regulation of bank capital

\begin{tabular}{|c|c|c|c|c|}
\hline \multirow[t]{2}{*}{ Explanatory variables $\downarrow$} & \multicolumn{2}{|c|}{ Two-stage least-squares regression } & \multicolumn{2}{|c|}{ Three-stage least-squares regression } \\
\hline & coefficients & t-stat & coefficients & t-stat \\
\hline \multirow{2}{*}{\multicolumn{5}{|c|}{$\begin{array}{l}\text { Capital level equation } \\
\text { Explained variable }=\Delta \mathrm{CAP}\end{array}$}} \\
\hline & & & & \\
\hline$\triangle \mathrm{ROA}$ & $0.002^{*}$ & $(1.628)$ & -0.001 & $(-0.028)$ \\
\hline$\Delta \mathrm{RISK}$ & -0.003 & $(-1.045)$ & -0.003 & $(-1.102)$ \\
\hline TCA & -0.001 & $(-0.171)$ & -0.001 & $(-0.086)$ \\
\hline ADEXT & -0.000 & $(-0.027)$ & $-0.004^{*}$ & $(-1.706)$ \\
\hline ADETAT & 0.000 & $(1.088)$ & 0.000 & $(1.168)$ \\
\hline ADINST & $-0.007^{* \star}$ & $(-2.021)$ & -0.001 & $(-0.113)$ \\
\hline REG1 & 0.005 & $(1.074)$ & 0.003 & $(1.028)$ \\
\hline $\mathrm{CAP}_{\mathrm{t}-1}$ & $-0.410^{\star \star \star}$ & $(-2.732)$ & $-0.372^{* * *}$ & $(-3.126)$ \\
\hline _cons & 0.026 & $(1.377)$ & 0.021 & $(1.475)$ \\
\hline & & & & \\
\hline \multicolumn{5}{|c|}{$\begin{array}{l}\text { Risk equation } \\
\text { Explained variable }=\Delta \text { RISK }\end{array}$} \\
\hline$\triangle \mathrm{ROA}$ & 0.001 & $(0.240)$ & 0.283 & $(0.462)$ \\
\hline$\triangle \mathrm{CAP}$ & $21.607^{\star \star}$ & $(2.127)$ & $31.390^{\star *}$ & $(2.259)$ \\
\hline TCA & -0.167 & $(-0.082)$ & -0.136 & $(-0.343)$ \\
\hline ADEXT & 0.012 & $(0.571)$ & 0.039 & $(1.534)$ \\
\hline ADETAT & 0.014 & $(0.302)$ & 0.054 & $(1.214)$ \\
\hline ADINST & $0.021^{\star *}$ & $(1.684)$ & 0.004 & $(0.394)$ \\
\hline LIQUID & 9.032 & $(1.212)$ & $16.561^{* *}$ & $(2.885)$ \\
\hline PROV & 0.009 & $(0.835)$ & 0.002 & $(0.097)$ \\
\hline REG1 & 0.147 & $(1.094)$ & $0.168^{*}$ & $(1.686)$ \\
\hline $\mathrm{RISK}_{\mathrm{t}-1}$ & $-0.206^{*}$ & $(-1.874)$ & $-0.144^{*}$ & $(-1.851)$ \\
\hline _cons & -3.602 & $(-1.185)$ & $-7.939^{\star * *}$ & $(-2.629)$ \\
\hline \multicolumn{5}{|l|}{ Performance equation } \\
\hline \multicolumn{5}{|c|}{ Explained variable $=\Delta R O A$} \\
\hline$\triangle \mathrm{CAP}$ & $22.512^{*}$ & (1.671) & $39.642^{\star *}$ & $(2.386)$ \\
\hline
\end{tabular}




\begin{tabular}{|c|c|c|c|c|}
\hline$\Delta \mathrm{RISK}$ & 0.159 & $(0.980)$ & 0.119 & $(1.354)$ \\
\hline TCA & $-0.280^{*}$ & $(-1.798)$ & $-0.290^{*}$ & $(-1.694)$ \\
\hline ADEXT & -0.016 & $(-1.132)$ & -0.013 & $(-1.126)$ \\
\hline ADETAT & -0.018 & $(-0.053)$ & -0.010 & $(-0.653)$ \\
\hline ADINST & $0.029^{* *}$ & $(2.172)$ & $0.029^{\star *}$ & $(2.271)$ \\
\hline LIQUID & $-10.080^{*}$ & $(-1.606)$ & $-9.013^{*}$ & $(-1.724)$ \\
\hline REG2 & -0.525 & $(-0.113)$ & -0.495 & $(-0.225)$ \\
\hline $\mathrm{ROA}_{\mathrm{t}-1}$ & -0.440 & $(-1.180)$ & -0.504 & $(-0.980)$ \\
\hline _cons & $4.603^{* * *}$ & $(3.805)$ & $4.374^{\star * \star}$ & $(3.000)$ \\
\hline $\mathrm{N}$ & 92 & & 92 & \\
\hline $\begin{array}{l}\text { Hansen-Sargan Statistics } \\
\text { P-value }\end{array}$ & $\begin{array}{l}12.65 \\
(0.085)\end{array}$ & & $\begin{array}{l}13.25 \\
(0.0816) \\
\end{array}$ & \\
\hline $\begin{array}{l}\text { Statistics of Hausman test } \\
\text { p-value }\end{array}$ & $\begin{array}{c}0.009 \\
0.894) \\
(0.964)\end{array}$ & & & \\
\hline
\end{tabular}

Superscripts ${ }^{*},{ }^{* *},{ }^{* * *}$ indicate statistical significance at 10\%, 5\%, and $1 \%$ levels, respectively; t statistics in parentheses.

For our system of equations, the Hausman test statistics reported in the last row of the table is not significant, suggesting that the estimation by the two-stage least-squares method is the most appropriate for the system. Moreover, the p-value associated with the Hansen-Sargan statistics being greater than 0.05 , we cannot reject the null hypothesis on the validity of the instruments used.

The results of the regressions show that changes in the level of capital positively influence the evolution of the performance and vice versa: a higher level of capital has a beneficial effect on the performance and vice versa, which tends to prove the effectiveness of capital regulation which requires a certain level of shareholders equity. The results obtained from estimating the model also shows that some variables related to internal governance board explain the evolution of capital, risk and performance of banks in Cameroon. On the contrary, regulatory pressure (REG1, REG2) explains none of the three endogenous variables.

In the capital ratio equation, a variable of governance seems to explain the evolution of bank capital. Indeed, the presence of institutional directors on the board is negatively related to the evolution of the capital ratio of the bank: an increased control seems to be related to a decrease in changes in the level of capital required to support the risks taken by the bank. This result suggests a substitution of the control exercised by the Board of directors by regulatory pressure as underscored by Booth et al. (2002).

Control by institutional directors has a positive influence on the performance of Cameroonian banks because these directors require managers to manage in the best interests of shareholders. This increase in performance is accompanied by an increase in risk taking (since ADINST is positively related to $\triangle \mathrm{RISK}$ ) and a reduction in capitalization (negative influence of ADINST on $\triangle \mathrm{CAP}$ ). Thus, the trade-off between risk and return is made with the aim to meet the expectations of shareholders, under the control of institutional directors.

The risk equation shows a positive relationship between the change in capital and the risk. Thus, following an increase in the capital ratio, the managers of Cameroonian banks invest in riskier activities. This result also obtained by Alexandre and Bouaiss (2008) argues in favor of shareholder discipline: to meet the demands for returns emanating from the providers of capital, i.e. shareholders, a bank obliged to have a higher capital adequacy ratio will increase risk taking. Put together, our results suggest that faced with both pressures exerted in opposite direction on the one hand by the shareholders (profitability requirement) and secondly by regulation (stress risk level) managers favour the interests of shareholders at the expense of the regulatory authorities.

\section{CONCLUSION}

The objective of this paper is to analyze the impact of the interaction of external mechanisms and different internal mechanisms of corporate governance on the performance of banks in Cameroon. The study is motivated by the fact that the decade 2001-2010 was marked by the strengthening of prudential supervision after the difficulties faced by banks in the late 1980s. Meanwhile, the restructuring of the banking sector and the entry of new banks in the market have intensified competitive pressure. To these external governance mechanisms is added the control implemented internally (by the shareholders and the board of directors). In this context, the risk of duplication of control is large, which is not without cost to the bank. We therefore examined whether the competitive pressure and regulatory pressure supplement or substitute the various internal controls to mitigate the agency problems and produce a good performance.

Globally, our results show an effect of complementarity between the control exerted by internal stakeholders (institutional shareholders, insiders' ownership, size of the board of directors) and competitive pressure. These complementary relationships show that these stakeholders exercise more effective control when competition increases in the loan market and help make the bank most productive. The results also suggest that managers, facing pressures exerted in the 
opposite direction on the one hand by the shareholders (profitability requirement) and secondly by regulation (stress risk level), favour the interests of shareholders at the expense of the regulatory authorities. Thus, in view of our results, it appears that managers meet the requirements of profitability of shareholders with a certain amount of risk, which clearly can exceed the level required by the regulations put in place by the Banking Commission. This result suggests a substitution of the control exercised by the board of directors with the regulatory pressure.

Nevertheless, this study has some limitations. The first is related to the difficulty in collecting information mainly because of confidentiality inherent in the banking industry, highlighting a feature of this sector which is opacity. The second limitation of this research relates to the approximations made to measure certain variables. We think especially of the assimilation of the percentage of capital held to the percentage of voting rights and the independence of the board. Future research could, if there will be the requisite data, adopt more subtle measures and provide clearer results. In addition, other features such as the board of directors' competence and frequency of meetings could be considered in future research.

\section{REFERENCES}

[1] Alexandre, H., \& Bouaiss, K. 2008. The complementarity of regulatory and internal governance mechanisms in banks. Banquers, Markets \& Investors, 98, 6-15.

[2] Ammann, M., Osech, D., \& Schmid, M. 2010. Product market competition, corporate governance, and firm value: evidence from the EU-area. Working Paper.

[3] Arellano, M., \& Bond, S. 1991. Some tests of specification for panel data: Monte Carlo evidence and an application to employment equations. Review of Economic Studies, 58, 277-297.

[4] Blundell, R., \& Bond, S. 1998. Initial conditions and moment restrictions in dynamic panel data models. Journal of Econometrics, 87(1), 115-143.

[5] Bond, S. 2002. Dynamic panel data models: a guide to micro data methods and practice. Portuguese Economic Journal, 1, 141-162.

[6] Booth, J.R., Cornett, M., \& Tehranian, H. 2002. Boards of directors, ownership and regulation. Journal of Banking and Finance, 26(10), 1973-1996.

[7] Bouaiss, K. 2008. Réglementation du Comité de Bâle, prise de risque et performance des banques européennes. Banque \& Marchés, 95, 6-14.

[8] Bouaiss, K., \& Marsal, C. 2009. Les mécanismes internes de gouvernance dans les banques : un état de l'art Finance Contrôle Stratégie, 12(1), 93-126.

[9] Chou, J., Lilian, Ng, Sibilkov, V., \& Wang, Q. 2011. Product market competition and corporate governance. Review of Development Finance, 1(2), 114-130.

[10] Dannon, P. H. 2010. Déterminants de l'efficience et de la probabilité de défaut bancaires : cas des pays de la zone UEMOA. Papier de recherche. Université d'Angers

[11] Giroud, X., \& Mueller, H. 2011. Corporate Governance, Product Market Competition, and Equity Prices. Journal of Finance, 66, 563-600.

[12] Gorton, G., \& Rosen, R., 1995, Corporate control, portfolio choice, and the decline of banking. Journal of Finance, 50(5), 1377-1420.

[13] Gorton, G., \& Winton, A. 2002. Financial intermediation. NBER Working Paper No. 8928.

[14] Grosfeld, I., \& Tressel, T. 2001. Competition and corporate governance : substitutes or complements ? Evidence from the Warsaw stock exchange. William Davidson Institute Working Paper No. 369. University of Michigan. Retrieved June 8, 2012, from http://www.delta.ens.fr/abstracts/200106.html

[15] Hausman, J. A. 1978. Specification test in econometrics. Econometrica, 46(6), 1251-1271.

[16] Januszewski, Silke, I., Koke, J., \& winter, J.K. 1999. Product market competition, corporate governance and firm performance: An empirical analysis for Germany: Discussion paper No. 99-63. Centre for European Economic Research.

[17] Karuna, C. 2010. Industry product market competition and corporate governance. Working Paper. University of California.

[18] Koke, J. 2001. Corporate governance, market discipline, and productivity growth. Discussion paper No. 01-55. Centre for European Economic Research.

[19] La Porta R., Lopez-de-Silanes, F., Shleifer, A., \& Vishny, R. 2000. Investor protection and corporate governance. Journal of Financial Economics, 58, 3-27.

[20] Li Weian \& Niu Jianbo. 2006. Product market competition and corporate governance in China: Complementary or substitute? IFSAM VIIIth World Congress, September 28-30, Berlin. Retrieved May 13, 2013, from www.ctwcongress.de/ifsam/download/track 1/pap00266 001.pdf pp. 1-15

[21] Macey, J., \& O'hara, M. 2003. The corporate governance of banks. Federal Reserve Bank of New York Economic Policy Review, 9(1), 91-107. 
[22] Manoranjan Pattanayak M., \& Pant Manoj. 2010. Corporate governance, competition and firm performance: Evidence from India. Discussion Paper 10-07. Centre for International Trade and Development School of International Studies Jawaharlal Nehru University India

[23] Maroto-Acin, J.A., \& Hernandez, M. 2000. Public administration as stakeholders in Spanish savings banks. In L. Shuster, Shareholder Value Management in Banks. Palgrave: Mac Millan.

[24] Nickell, J.S., Nicolitsas, D., \& Dryden, N. 1997. What makes firm perform well?. European Economic Review, 41, 783-796.

[25] Park, K. S., Byun, H.S., \& Lee, J. H. 2011. How does product market competition interact with internal corporate governance?: Evidence from the Korean economy. Working paper. Korea University Business School.

[26] Prowse, S. 1997. Corporate control in commercial banks. Journal of Financial Research, 20, 509-527.

[27] Randøy, T., \& Jenssen, J.I. 2004. Board independence and product market competition in swedish firms. Corporate Governance: An International Review, 12(3), 281-289.

[28] Sevestre, P. 2002. Econométrie des données de panel, édition Dunod.

[29] Shleifer, A., \& Vishny, R. 1997. A survey of corporate governance. Journal of Finance, 52, 737-783.

[30] Shrieves, R.E., \& Dahl, D. 1992. The relationship between risk and capital in commercial banks. Journal of Banking and Finance, 16, 439-457. 